\title{
UM ENSAIO SOBRE O ROMANCE TODOS OS HOMENS SÃO MORTAIS
}

\author{
Paula Priscila Braga ${ }^{2}$, Vinicius Ramos Pires ${ }^{3}$
}

\section{Resumo}

Este artigo tem por finalidade analisar o romance Todos os Homens são Mortais, da escritora francesa Simone de Beauvoir. Tomando como foco da análise as duas personagens principais, o conde Raymond Fosca e a atriz Régine, propõe-se uma leitura interpretativa do enredo do livro em seus principais momentos e nas suas temáticas mais fundamentais - finitude, liberdade, o sentido da história e da vida - a partir do auxílio teórico de três autores vinculados à tradição da filosofia existencial: Heidegger, Sartre e Camus.

Palavras-chaves: Finitude, Existencialismo, Beauvoir.

\begin{abstract}
This text discusses the novel All Men are Mortal by French writer Simone de Beauvoir. Focusing on the analysis of the two main characteres, Duke Fosca and the actress Régine, it proposes an interpretative reading of the main passages of the book and their fundamental themes -- finitude, freedom, the meaning of life and of history -- departing from the theoretical production of three authors:

Heidegger, Sartre and

Camus.
\end{abstract}

Keywords: Finitude, Existentialism, Beauvoir.

\footnotetext{
${ }^{1}$ Todos os Homens são Mortais é um romance escrito por Simone de Beauvoir publicado originalmente em 1946. Insere-se no contexto das discussões do chamado "existencialismo francês", que não sendo propriamente uma escola ou uma corrente filosófica, reúne sob o epíteto alguns autores que se concentraram na construção de análises da existência humana com ênfase, sobretudo, no seu caráter indeterminado e constantemente criativo. Alguns destes autores ultrapassaram o âmbito mais técnico da filosofia ligada à fenomenologia para trabalhar suas ideias também através da arte, em especial na literatura e no teatro. Além de Simone de Beauvoir, são eles Jean-Paul Sartre e Albert Camus, ambos laureados com o Nobel de Literatura.

2 Professora do curso de Filosofia na Universidade Federal do ABC. E-mail: p.braga@ufabc.edu.br

${ }^{3}$ Universidade Federal do ABC.
} 
Não há Vontade de Vida ou Potência, não há conatus que suficientemente exprimam essa paixão que é uma vida humana. Talvez é o que possamos concluir com maior segurança ao fim da leitura do romance Todos os Homens são Mortais, de Simone de Beauvoir. Pois ao colocar face a face a finitude e a imortalidade, o desejo pela eternidade e pela morte, a angústia pelo nada evidente e o tédio haurido de um presente que não encontra termo, não se encontra qualquer síntese que não esta: existir é estar insatisfeito. É o que se pressente cada vez mais claro ao se acompanhar a jornada estéril do protagonista do romance, Raymond Fosca, que em sua errância não faz senão buscar fugir à sua condição imortal enquanto que, indiretamente, porta como um arauto a evidência empalidecida de que todos os homens são mortais, que a morte é parte inexorável do existir humano, ainda que também seu mais sobejo absurdo. Mais do que isso, Fosca, em seu perpétuo exílio do tempo comum, vê a história humana da perspectiva de um periscópio que se ergue sobre ela, tão perto e tão longe das fulgurações e dramas das incontáveis vidas humanas, mas não à maneira de Deus, e sim como o mais miserável vivente. Assim, em forma de narrativa, Simone de Beauvoir articula um estudo que coloca em jogo a finitude humana, a história, a humanidade e o sentido da vida. A tarefa que nos cabe aqui, analisando Todos os Homens são Mortais, é explorar cada um desses temas, tendo como chave de compreensão do romance duas de suas personagens: o conde Raymond Fosca e a atriz Régine.

Régine está numa cidade do interior da França junto a sua companhia teatral, que ali promove uma temporada de apresentações. Nesse lugar, Régine se entedia, assiste o transcorrer lânguido e vazio dos dias. As horas mortas da província são um desperdício de vida, um longo suspiro de lamento pelo tempo que nunca será recobrado. Pesa-lhe este mundo que foge ao seu controle, este mundo no qual só é uma consciência finita e isolada, onde a multidão de existências independentes a ferem no âmago: "Por que sou assim? (...) Quando vejo em torno de mim pessoas que vivem e são felizes, parece-me que me assassinam" (BEAUVOIR, 1983, p.12). E suas inquietações que transbordam em meio à pasmaceira geral daquela vida exigem sempre as distrações, os espelhos, os olhares ávidos de outros mortais em um afã inesgotável de eliminar a imobilidade, pois, afinal, sombreando a tudo está a tácita noção de que a vida é efêmera e que toda experiência humana é limitada pela morte.

E é por isso que se ocupa de um homem que encontra no jardim do hotel onde está hospedada. Este passa os dias deitado no jardim, indiferente ao clima, às pessoas, ao mundo. 
Estático, é a antítese de Régine, de sua sede de consumir as horas inteiramente, com tudo o que podem oferecer:

Tenho inveja dele, não sabe que a terra é tão grande e a vida tão curta; não sabe que existem outras pessoas. Contenta-se com esse pedaço de céu acima de sua cabeça. Eu gostaria que cada coisa me pertencesse como se só a ela amasse no mundo; mas quero todas as coisas e as minhas mãos estão vazias. Invejo-o. Ele ignora seguramente o tédio (BEAUVOIR, 1983, p.14).

O homem invejado por sua imobilidade é Raymond Fosca. Saído de um hospício, torna-se para ela um objeto de distração. Tomando-o como um doente, diz pretender curá-lo, ocupar-se dele até que se canse e precise de outros estímulos, outras pessoas. Num primeiro momento, para Régine, Fosca não passa de um objeto, um jogo momentâneo, a ser abandonado quando conveniente, quando se tornar cansativo. E convém quando Régine já voltou a Paris, às vibrações permanentes da vida na capital, enlevada pela sociedade, os jantares, o sonho de atuar no cinema. Ali as cores ausentes nas horas morosas da província voltam a resplandecer, o tempo se preenche e Fosca pode se esfumar com os dias já idos do interior. O problema é que Fosca não é um objeto como os outros. Régine o resgatou da apatia, e agora tem que arcar com isso. Ele a persegue e procura sua atenção. Em uma dada noite consegue que Régine o ouça e revela-lhe a razão de sua estranheza: é imortal, e o prova talhando o próprio pescoço sem que morra. Desta cena, Régine pode extrair apenas pasmo - não um pasmo do incidente fantástico que presenciou, mas um pasmo íntimo, um pasmo perante a própria existência. Pois a imortalidade de Fosca é também, a Régine, a afirmação de sua própria finitude. Sabe-se a oposição dele; sabe-se uma mortal para quem tudo acaba. Tudo aquilo que faz, todas as suas experiências e pretensões devem acabar e desaparecer. Sua vida, seus propósitos e projetos empalidecem, pois forçosamente soçobrarão no nada:

O perfume dos narcisos é imortal, e também essa febre que inala meus lábios. Sou imortal. Amarfanha os narcisos entre as mãos. Era inútil. A morte estava nela e ela já o sabia, já a acolhia. Ser bela dez anos ainda, representar Fedra e Cleópatra, deixar no coração dos homens mortais uma pálida lembrança, que se faria em poeira aos poucos, pudera contentar-se com essas modestas ambições. (...) Um dia serei velha, um dia morrerei, um dia serei esquecida. E enquanto penso isso, há um homem que pensa:"Estarei sempre aqui". (BEAUVOIR, 1983, p.39)

Desde as primeiras páginas do livro, a morte preocupa a Régine. Ela estremece à ideia de ser "um fiapo de capim", de que o tempo possa ser desperdiçado. Quando contempla o quarto do hotel, sabe que sua presença naquele cômodo não deixará vestígio algum, que aquele espaço e os móveis permanecerão apesar dela, indiferentes sempre, e que aquela cama vazia abrigará ainda o 
corpo de muitas outras mulheres que ignorarão que ali também dormira a atriz Régine. Entretanto, do contato com Fosca, o que a morte é, como a percebe, se transfigura. Abandona a morte o seu caráter cotidiano, e deixa de ser uma possibilidade vaga para ser uma possibilidade concreta, inexorável.

Esses dois modos de apreender o fenômeno da finitude podem ser compreendidos à luz da filosofia de Heidegger. Segundo este autor, como expõe em Ser e Tempo, nós humanos denominados ser-aí a fim de evitar pressupostos fílosóficos e científicos - temos um modo de ser distinto das outras coisas, pois, ao contrário delas, não podemos ser caracterizados por uma essência determinada: “A essência do ser-aí está em sua existência” (HEIDEGGER, 2015, p.85). Isso quer dizer que nada define um ser humano de forma apriorística à própria existência, pois é um ente que está sempre em jogo em seu ser, aberto ao mundo do qual faz parte e habita, lidando com as coisas e convivendo com os outros, sendo a cada instante suas possibilidades; em suma, um ser que é poder-ser. Mas, dentre todas as possibilidades abertas a alguém, uma desponta com primazia: a morte. E não só como um fato empírico de um acontecimento exterior que sobrevém aos que vivem, mas como uma possibilidade ontológica irrecusável. Cada ser humano, a medida que é poder-ser, tem constitutivamente a possibilidade de não-ser, a possibilidade de deixar de ser-no-mundo e, por consequência, de ter possibilidades. Portanto:

Essa possibilidade mais própria e irremissível é, ao mesmo tempo, a possibilidade mais extrema. Enquanto poder-ser, o ser-aí não é capaz de superar a possibilidade da morte. A morte é, em última instância, a possibilidade da impossibilidade pura e simples do ser-aí. Desse modo, a morte desvela-se como a possibilidade mais própria, irremissivel e insuperável. (HEIDEGGER, 2015, p.326)

Assim, o ser humano é um ser que finda, que é ser-para-a-morte, pois, à diferença de todas as coisas do mundo, ele tem de lidar com a certeza de que deixará de ser. Contudo, cabe ressaltar que se é sempre no mundo. Cada um se ocupa deste mundo cotidianamente, onde se mergulha distraidamente, onde o cotidiano preenche tudo e todos se enfronham na banalidade de cada ação. Ao ser-para-a-morte também não é furtada essa tonalidade cotidiana. Não se nega a morte, mas pode-se tratá-la com eufemismos, encobri-la. É um fato empírico, acontece sempre, mas não tem o caráter de ser a possibilidade mais própria, irremissível, insuperável e certa. $\mathrm{Na}$ cotidianidade,

O impessoal encobre o que há de característico na certeza da morte, ou seja, que é possivel a todo instante. Junto da certeza da morte, dá-se a indeterminação de seu quando. O ser-para-a-morte cotidiano escapa dessa indeterminação, 
emprestando-lhe determinações. Essa determinação significa, porém, calcular quando se deixará de viver. O ser-aí, na verdade, foge dessa determinação. A indeterminação da morte certa determina as ocupações cotidianas, colocandolhes à frente as urgências e possibilidades previsíveis do cotidiano mais próximo (HEIDEGGER, 2015, p. 335).

No cotidiano, a morte não é um assunto de premência, pois diz respeito sempre a um futuro indeterminado. As coisas próximas, o dia-a-dia é que ganham a qualidade de urgentes. Pois ainda que de forma indeterminada, fato é que se morre. O reconhecimento mesmo que subterrâneo disso confere a cada atividade um prazo. Tudo é determinado a partir do fato que em algum instante desconhecido expirarão quaisquer possibilidades. A indeterminação da morte, em suma, veta que a vida em suas lidas corriqueiras seja sempre adiada. Mas o envolvimento mesmo com essas lidas, a preocupação constante com sua realização mascaram que em algum momento (que pode ser mesmo agora) há de se morrer. Régine, sempre ao pensar sobre sua própria morte, de pronto se empenha com qualquer tarefa. Sua ânsia em preencher o tempo é uma ânsia em mergulhar ao máximo no cotidiano, em sentir realizar tudo o que deseja. Não poderá fazê-lo para sempre. Mas ao conhecer a imortalidade de Fosca, Régine percebe que a morte não pode ser mascarada por qualquer coisa, e o que quer que faça, no fundo, é vão. Está agora submersa em angústia, mas não em relação às inseguranças corriqueiras, e sim quanto à própria existência, à evidência de que as coisas e a vida se desdobram sempre em nada. "O ser-para-a-morte é, essencialmente, angústia" (HEIDEGGER, 2015, p.343), diz Heidegger, pois nele está-se "frente ao nada da possível impossibilidade de sua existência" (HEIDEGGER, 2015, p. 335).

Podemos entender, então, que a morte está no horizonte de nossos atos. É porque morremos que não os adiamos indefinidamente. Ao estudarmos a personagem do conde Fosca, poderemos entender que a eternidade é capaz de mesclar tudo na pura indiferença. Mas por ora ainda consideremos a condição de um humano mortal. Se a morte pode ser o que faz com que vivamos nossas vidas cotidianas, por outro lado, ela faz da vida despropositada. Morrer é um absurdo, sobretudo se se compreende que um ser humano é um projeto constante de si mesmo.

Em O Ser e o Nada, Sartre, ao descrever a existência a partir das estruturas do Em-Si e do Para-Si, faz da vida pura inquietude. Essas duas expressões, Ser-Em-Si e Ser-Para-Si fazem parte do vocabulário técnico da filosofia de Sartre e aparecem com grande constância em O Ser e o Nada. O Em-Si é caracterizado pela seguinte fórmula: "O ser é. O ser é em si. O ser é o que é" (SARTRE, 1997, p.40). Isso quer dizer que o Em-Si é uma plenitude indiferenciada; ou seja, não 
é ativo ou passivo; não é afirmação ou negação, mas apenas o seu meio. Em suma, simplesmente é. Por sua vez, o Para-Si é o modo de ser que age, sendo relacionado à consciência. Ele é o que caracteriza propriamente os seres humanos. Enquanto que o Em-Si é uma plenitude positiva de ser, o Para-Si, relativo à consciência (entendida fenomenologicamente como consciência de alguma coisa), é negação. O Para-Si caracteriza-se então por negar o Em-Si e o faz sempre em razão de um nada possível; quer dizer, a partir da projeção de uma situação futura tomada como possibilidade. Como consequência, tem-se uma concepção dinâmica do indivíduo humano. Ele nunca é simplesmente ser, acabado e passível de uma definição derradeira. Pelo contrário, um ser humano está sempre negando a si mesmo em razão de uma situação futura que ele vislumbra e toma para si. Daí a famosa afirmação de Sartre de que "(...) a existência precede a essência" (SARTRE, 1997, p.695), pois não há uma definição a priori possível do que é um ser humano, não há a consideração e a determinação de uma natureza humana. O que um indivíduo é é o que ele se faz, e mesmo assim nunca será algo acabado enquanto respirar. Mais do que isso: cada um é entendido como absolutamente livre, o que não significa fazer tudo o que pretender, mas que nunca se pode reportar os próprios atos à responsabilidade de outro e que nunca se pode deixar de escolher, o que implica na paradoxal condenação à liberdade. E tudo isso entendido de forma situada; ou seja, permeada por uma dada facticidade, uma situação histórica, social e biológica já determinada. É o que permite a Beauvoir (2005) entender a condição humana como ambígua: ninguém se reduz simplesmente ao seu contexto, mas ninguém também pode se desenraizar desse mesmo contexto. 4

Deste modo, fica clara a condição de permanente inquietude que é a do ser humano: este está entre o ser e o nada, em uma constante carência de ser algo como as coisas paralisadas, que se pode mirar e definir como um ser acabado e permanente. Padece pelo inatingível, e sua busca se constitui inacabável. Todo projeto humano não é mais que a ânsia por fundamento e repouso.

\footnotetext{
${ }^{4}$ Tal recusa de uma essência e predeterminação dos indivíduos humanos desempenha um papel importante na própria filosofia de Simone de Beauvoir, principalmente se considerarmos seu longo livro O Segundo Sexo (1949), onde aparece à famosa afirmação "Ninguém nasce mulher: torna-se mulher" (BEAUVOIR; 1967, p. 9). Aqui Simone de Beauvoir não nega que existam indivíduos humanos pertencentes ao sexo feminino, mas recusa que o modo como as mulheres vivem e se comportam socialmente - como o segundo sexo, o negativo da humanidade - seja algo que faça parte de uma essência do sexo feminino, algo determinado ou por força divina ou então biológica e psicológica. O ser mulher é algo que surge a partir de um contexto social, diferenciando assim o sexo do gênero. Assim, "Nenhum destino biológico, psíquico, econômico define a forma que a fêmea humana assume no seio da sociedade; é o conjunto da civilização que elabora esse produto intermediário entre o macho e o castrado que qualificam de feminino" (BEAUVOIR; 1967, p. 9).
} 
Tudo, contudo, se frustra, e a paixão da busca permanece em aberto. Antes de tudo, ser humano é uma paixão inútil:

Toda realidade humana é uma paixão, já que projeta perder-se para fundamentar o ser e, ao mesmo tempo, constituir o Em-si que escape à contingência sendo fundamento de si mesmo, o Ens causa sui que as religiões chamam de Deus. Assim, a paixão do homem é inversa à de Cristo, pois o homem se perde enquanto homem para que Deus nasça. Mas a ideia de Deus é contraditória, e nos perdemos em vão; o homem é uma paixão inútil. (SARTRE, 1997, p.742).

À luz disso podemos entender a inveja que Régine nutre quando vê Fosca pela primeira vez: aquele homem que "seguramente ignora o tédio" é certamente um ser acabado, pleno e indiferente, e por isso mesmo livre do movimento sem descanso de buscar ser, pois já o é. Podemos também entender a angústia que lhe desperta a certeza de sua mortalidade, pois Régine é toda essa paixão inútil e sem fundamento, que vive e morre sem razão. Morrer é absurdo porque na morte há o enunciado extremo de que a busca humana por ser é irrealizável. "Nossa vida não é mais que uma longa espera" (SARTRE, 1997, p.659) de ser, diz Sartre. Mas morrer significa justamente que essa espera é vazia, e que jamais pode passar de apenas uma espera. "Se sou espera de esperas de espera, e se, de súbito, o objeto da minha última espera e aquele que espera são suprimidos, a espera recebe respectivamente o caráter de absurdidade" (SARTRE, 1997, p.660-661).

Assim, Régine, em sua finitude, é absurda. Nada do que pretenda pode se converter em uma concretização definitiva. Todas as pretensões estão legadas ao fracasso. Régine não só está condenada a perecer, mas também a fracassar. Suas esperas hão de sempre ser vãs. E não há o que pode servir-lhe de consolo, pois a angústia do nada que a toma não diz respeito somente à morte. É um sinal também de seu abandono, pois toda a sua vida só pode ser determinada por ela mesma, por sua consciência livre, pois mesmo o passado não pode forçá-la a qualquer escolha por vir. A angústia é também apreensão de sua própria liberdade. 5

Não surpreende então seu desespero. Tudo que era sua vida - o sonho de atuar no cinema, as pessoas com que se relacionava - é abandonado. O grito de horror que solta ao final do romance exprime esse abandono e a clareza de que as aparas do mundo desabaram impiedosamente. Se se apaixona por Fosca, é uma paixão que verte do seu desespero, do desejo de anular seu próprio absurdo, pois quem sabe se não pode superar sua própria mortalidade através do amor de Fosca, na forma de uma lembrança carregada eternamente? Assim, "ela

\footnotetext{
${ }^{5}$ Cf. Sartre, O Ser e o Nada, 1997, p.77.
} 
amava-o porque ele era imortal, e ele amava-a na esperança de tornar a ser semelhante a um mortal" (BEAUVOIR, 1983, p.66). Porque em Fosca também não podemos encontrar o repouso, mas apenas tempestade. Sua condição é marcada pela insatisfação, pela busca do inatingível, pois, afinal, "Vivo e não tenho vida. Não morrerei nunca e não tenho futuro. Não sou ninguém. Não tenho história nem fisionomia" (BEAUVOIR, 1983, p.36). Sua eternidade é um interdito a uma vida humana comum. Amar Régine é tentar voltar para o seio do mundo dos mortais, reconquistar o hábito do tempo e sua passagem. Não pode agonizar por sua própria finitude, mas apenas pela de Régine. Amando-a sabe que a perderá para a morte, e então o tempo é contado a partir dela. O tempo dela é seu tempo. Sua vida só transcorre a partir dela. Existe humanamente enquanto tem-na para amar. Com a morte de Régine, extinguem-se para ele, mesmo que sob a forma de intermitência, o tempo e a existência. No fundo, Régine é para ele como uma ampulheta.

Ademais, Fosca, no todo do romance, atua como um contraponto a Régine e ao dado mais imediato da condição humana: a finitude. Simone de Beauvoir quando toma em relevo Régine narra sempre em terceira pessoa, não obstante o predominante uso de fluxos de consciência. $\mathrm{O}$ foco se volta a um indivíduo, ao sufoco de suas angústias e desespero. Já quando Fosca torna-se o elemento preponderante do romance, a narrativa converte-se inteiramente à primeira pessoa. Aqui é Fosca que relata sua vida, conta-a a Régine. Tudo a partir de uma perspectiva individual é verdade, mas projetando-a, contudo, em considerações de dimensão histórica e coletiva, pois Fosca, em posse de sua imortalidade, ainda que a partir de um olhar individual, constitui outro olhar, um olhar sem tempo, que abrange o todo, para além de uma exclusiva e limitada situação histórica. Todos os Homens são Mortais, excetuando-se o Prólogo, é um exercício de imaginação e exposição desse olhar. Por isso cabe-nos agora deter também a atenção em Fosca e sua estória.

Fosca nasceu em 1279, numa família nobre da cidade fictícia de Carmona, na Itália. Cresceu sob o governo despótico do duque Francisco Rienzi, malquisto pela população, considerado culpado da miséria e do estado de abuso em que viviam os cidadãos de Carmona. Quando da sua morte, é substituído pelo filho, Bertrando Rienzi, que não demora muito para ser assassinado e substituído no posto. $\mathrm{O}$ que se segue é uma sucessão violenta de assassinatos e substituições dos líderes da cidade, até que Fosca assume o governo, em 1311. Em um primeiro momento, seu destino é semelhante ao dos seus antecessores. Carmona permanecia na mesma penúria, sempre metida em guerras, e com um governante igualmente despótico. Sob um cerco do 
exército genovês, Fosca evacuara a cidade já sem suprimentos, enviando as mulheres, crianças e os inválidos aos fossos juntos das muralhas, de modo que ali morressem sob o ataque e servissem, pela pestilência de sua decomposição, como arma contra o exército rival. Bartolomeu, um mendigo de 80 anos, que também estava sendo conduzido às muralhas, ofereceu a Fosca, em troca de sua libertação, uma poção egípcia que garantiu ser o elixir da imortalidade. Primeiro, como teste, deram-na a um camundongo, que desfaleceu e depois retornou à vida, supostamente imortal. Depois a tomou Fosca, que desacordado por quatro dias, voltou à vida, agora imortal e invulnerável, como um deus que podia dispor da vida dos mortais e que se dedicaria a fazer de Carmona a maior potência da Toscana. Num primeiro momento, a imortalidade é uma dádiva e o sinal da libertação, de um homem agora estranho ao império da mortalidade. Tudo lhe era possível e permitido:

Eu vivia e não tinha semelhantes. O passado saíra de mim; nada mais me prendia; nem lembrança, nem amor, nem dever; estava sem lei, era meu dono e senhor, podia dispor à vontade das pobres vidas humanas, todas votadas à morte. Sob o céu sem expressão, eu me erguia vivo e livre, só para todo o sempre (BEAUVOIR, 1983,p.123).

E por todo o medievo, Fosca devotou sua nova liberdade e solidão à ambição. Viu Carmona enriquecer e empobrecer, viu-a superpopulosa e rica, e depois devastada pela peste, que levou junto sua família. Envolveu-se em diversas guerras, venceu e perdeu batalhas, viu suas tropas massacrarem outras e depois serem massacradas. E dentro da própria Carmona, viu revoltas da população respondidas com chacinas para a manutenção do poder. Tudo sempre o mesmo. As idas e vindas dos mortais, as mudanças e os acontecimentos principiavam a perder o brio. Todos os esforços e batalhas, toda violência eram em vão. Nada se modelava à sua ambição e tudo exibia um fundo de insuficiência. O mundo, com o passar dos séculos, enfastia: "Dia após dia os mesmos gestos. (...) Infinitamente! Não me acontecerá nunca despertar num outro mundo onde até o gosto do ar seja diferente?" (BEAUVOIR, 1983, p. 140).

Para a infelicidade de Fosca, não. Sejam as estátuas de Carmona ou Carmona mesmo; seja a natureza ao redor e a monotonia do céu, nada mostrava-se significativo, disponível para algum fim qualquer. $\mathrm{O}$ mundo, antes infinito aberto às conquistas da liberdade solitária de Fosca, começa, após decorridos duzentos anos, a ser apenas uma maciça inutilidade. Impressão que cada vez se torna mais nítida. Qualquer projeto de Fosca não é mais do que um fracasso. Qualquer coisa em que se empenhe é ineficaz para conter o aborrecimento que inunda-lhe a vida. Essa 
liberdade que Fosca julgava ilimitada, prova-se, em verdade, restrita, reduzida às meras possibilidades humanas. É uma conclusão que se impõe cada vez mais certa no decurso do tempo, a cada nova empreitada movida por Fosca.

Primeiro através de Alberto, filho que decide ter. Fosca programa-lhe a vida, lhe dispõe todos os meios e luxos para que seja os mais feliz dos mortais, livre das misérias que se abatem invariáveis sobre cada pessoa. Mas isso não é possível, não é mais que uma pretensão voltada ao fracasso. Pois Alberto, contrariando os desejos do pai, abdicou ao modelo de vida suposto perfeito por Fosca para morrer em um campo de batalha defendendo Carmona. É que, apesar de imortal, Fosca também está isolado à condição de uma consciência solitária. Para além de si mesmo - diferente do que concebia - nada pode. É inútil desejar realizar na pessoa de Alberto qualquer suposição de felicidade. Pois não pode dispor de um outro, não pode suprimir sua liberdade de outra forma que não a aniquilação. Assim, apenas Alberto poderia decidir por seu ser. Em verdade, não se pode fazer cativa uma transcendência alheia, não se pode realizar em outrem um projeto de si mesmo.

E isso não só no que tange à vida de um indivíduo em particular. A humanidade, o seu todo, nega-se a molduras e imposições, nega-se à imputação de um modelo primordial, a uma determinação da vida que venha do exterior aos indivíduos. Ninguém pode forçar a humanidade à felicidade ou qualquer coisa do tipo. As escolhas e determinações de uma vida sempre se resumem ao âmbito estreito da solidão. Fosca descobre que não pode ensinar a humanidade a querer qualquer coisa para além do que buscam os indivíduos em seus projetos privados e anônimos. E descobre isso justamente na presença aterradora da violência, repressão e genocídio. Pois logo após a morte de Alberto, enquanto o céu de Carmona era chamuscado pelas luzes dos fogos reverentes a mais uma guerra vencida, Fosca percebe a inocuidade de querer a realização de ideias dentro das limitações de uma cidade-estado italiana: isso só se realiza caso se tenha o mundo em mãos. E então entrega Carmona aos Habsburgos e se junta à sua corte. Como conselheiro de Carlos V6, rei da Espanha durante o princípio da exploração das Américas,

\footnotetext{
${ }^{6}$ Carlos V ou Carlos I da Espanha (1500-1558) é um membro das dinastia dos Habsburgos que acumulou as coroas do Sacro Império Romano-Germânico e do Reino da Espanha além de Arquiduque da Áustria. Seu governo caracteriza-se sobretudo pelo combate ao nascente protestantismo cristão e por conflitos territoriais dentro da Europa, tendo como principal adversário a França. No romance, Fosca é o conselheiro e mentor de Carlos V, aquele que está por trás de todas as atitudes do monarca. Seu objetivo é unificar todos os indivíduos sob um mesmo regime de ideias, de forma que sejam governados rumo à felicidade. É por isso que no contexto do romance há, por exemplo, o combate ao protestantismo.
} 
pretende unir a terra toda e, assim, governar o mundo sob sua razão particular: "Administrarei o mundo com a mesma economia com que administrei outrora os celeiros de Carmona. Nada será entregue aos caprichos dos homens nem aos acasos da sorte. A razão governará a terra: minha razão" (BEAUBOIR, 1983, p.180). E mais uma vez o fracasso: nada há na Europa para além de guerras territoriais; miséria e repressão aos revoltosos; perseguição aos protestantes e sua pretensão de comunicar-se com Deus diretamente pela consciência; genocídio e escravização dos indígenas nas Américas. Sob a tentativa de unificar o mundo, de impor-lhe uma razão que ele mesmo não tem, nada há além de uma mácula de sangue que escorre por toda a Terra. De tudo isso, de todas suas experiências de ambição e poder, de Carmona até a extensão da Terra, não há nenhuma conclusão possível além desta: "Eu tinha um filho. (...) Escolheu morrer porque eu não lhe deixara outro modo de viver. Tinha uma mulher também, e, porque lhe dei tudo, morreu viva. E há muitos que queimamos e expiraram agradecendo-nos. Não é a felicidade que querem: é somente viver." (BEAUVOIR, 1983, p.235). Pois, no fim, nada pode ser imposto aos seres humanos de modo que eles tenham de aceitar. É a sua condição de acordo com o que vimos com Sartre: negar o Em-si, essa realidade que se entrega bruta a uma consciência que não é nada além de um nada que busca ser. Nenhum paraíso pode ser criado e entregue pronto às pequenas vidas humanas, pois elas não são senão um gesto que se lança ao futuro, uma espera constante que busca criar e realizar. Cada um é uma paixão e uma inutilidade que não pode cessar de ser isso que é: uma criação insensata, ardente e perpétua de si mesmo. E é à base de toda a experiência, de toda a tentativa de impor ao mundo um projeto que era apenas seu, que Fosca compreende essa verdade.

Agora eu os compreendo. O que vale a seus olhos não é nunca o que recebem, é o que fazem. Se não podem criar, precisam destruir, mas de qualquer maneira devem recusar a realidade; do contrário, não seriam homens. E a nós, que pretendemos forjar o mundo por eles e encerrá-los dentro, a nós só nos podem odiar. Essa ordem, essa tranquilidade com que sonhamos, seria para eles a pior das maldições... (BEAUVOIR, 1983, p.235).

Mas para Fosca há ainda mais do que a impossibilidade de criar um mundo sob o véu de suas ideias e desejos. Além dos fracassos constantes, sobre ele pesa uma sina que o coloca distante do resto da humanidade. Para esta, o tempo corre, os indivíduos nascem e deixam de ser sucessivamente, embrenhados no ordinário de suas vidas, em seus vãos esforços. Mas essa inutilidade absurda corriqueira de toda vida humana é experienciada diversamente por Fosca, pois em seu caso não há como abandoná-la. Mesmo que em cada momento de sua narrativa se 
alterem os tons, os atores e os cenários, o que se desempenha é sempre o mesmo a fundo. Fosca é um estrangeiro entre os humanos. Avizinha-se somente do céu profuso da noite incandescido pelo brilho maldito da lua, pois estes também são constâncias que não desaparecem com os anos. No tocante ao mundo humano, toda tentativa de tornar a habitá-lo é falha. Depois que abandona a corte espanhola, vaga a esmo pelo mundo até que encontra na América do Norte, Carlier, um explorador que deseja encontrar uma passagem direta dali à China. Fosca o encontra à beira da morte, salva-lhe a vida, toma parte em seu projeto, mas tudo em vão: Carlier, ao saber da imortalidade de Fosca, se suicida. Já na França do século XVIII, Fosca não passa de um burguês que age indiferente a tudo e a todos. Busca voltar à vida comum quando cai apaixonado por Marianne $^{7}$, com quem se casa. Contudo, não pode dissimular para si mesmo que a ela o tempo corre vertiginosamente, enquanto ele mesmo é imune à morte. E basta que Marianne descubra sua imortalidade, para que a vida reconquistada volte a ruir. A incompatibilidade no que diz respeito ao que se é no tempo aqui é insuperável: "Dei-me a ti inteiramente. - disse ela - Pensava que te davas também para a vida e para a morte. E tu te emprestavas por alguns anos" (BEAUVOIR, 1983, p.319). Como tudo o que há no universo de Fosca, Marianne não pode também ser mais que uma memória fugaz, predestinada a se perder nos anos e tornar-se nada para além de um nome vago. Ante essa situação, ela ainda o aconselha a "Tentar ser homem entre os homens. Não há outra solução para ti”" (BEAUVOIR, 1983, p.323). Mas tampouco esse conselho porta uma solução. Porque mesmo que Fosca se envolva com a Primavera dos Povos, lute junto às barricadas com os revolucionários, tudo isso não lhe diz respeito de fato, não pode afetá-lo para além da indiferença. Tudo aquilo era para nada, todos morrem por nada, mesmo que seja buscando algo que está além deles mesmos.

Não podia suportar ouvi-los falar com ardor desses dias em que até sua lembrança estaria apagada sobre a terra; Talvez fosse isso o que me separasse deles irremediavelmente: viviam voltados intensamente para um futuro em que se realizaram todos os seus esforços presentes. E para mim o futuro era um

\footnotetext{
${ }^{7}$ Podemos cogitar que Beauvoir não atribuiu o nome Marianne gratuitamente à personagem. Afinal, Marianne é o nome da efígie da república francesa, considerada uma representante do povo francês durante o século XVIII e uma alegoria da liberdade a partir da Revolução Francesa. Sua figura é representada como uma mulher trajando um barrete frígio na cabeça, eternizada por Delacroix em seu quadro A Liberdade Guiando o Povo. No romance, a personagem Marianne é uma mulher absolutamente afinada com as ideias e os projetos da Ilustração Francesa que foram decisivos à revolução principiada a 14 de julho de 1789. Isso se exemplifica nos esforços que a personagem faz em prol da criação de uma universidade pública a fim do desenvolvimento e disseminação do conhecimento científico. Em um plano figurativo, podemos estimar que Marianne signifique liberdade para o conde Fosca, pois a partir de seu relacionamento com ela, ele pode se libertar, mesmo que temporariamente, do seu martírio existencial e viver como uma pessoa comum.
} 
tempo estranho, detestado; o tempo em que Marianne estaria morta, em que a vida me apareceria enterrada no fundo dos séculos, inútil, perdida; e esse tempo destinava-se a ser por sua vez enterrado, perdido e inútil. (BEAUVOIR, 1983 , p.310).

Fosca, apartado do mundo humano, impedido de ser "homem entre os homens" vive à parte da história. Para ele, o tempo é um determinante apenas da perda dos outros, dos amores e dos desejos que resvalam sobre pessoas. Afora isso, os rumos do mundo são-lhe indiferentes. Sejam quais forem as direções da história, ele estará lá, assistirá a tudo, como um estranho, como alguém que não pode ser afetado pelos acontecimentos. Nessa situação, o tempo não é mais que um coágulo, uma imobilidade à guisa de um Ser parmenídico eternamente idêntico a si mesmo, uma subjacência inerte à tumultuosa mudança dos fenômenos. E como um olho estranho à história, Fosca pode perceber que ela se move em direção a coisa alguma, não segue nenhum ideal e determinações a priori. A história e seus momentos são só a partir do que fazem dela os humanos, ela é um acontecimento simultâneo às milhares de existências que estão presas a ela na mesma medida que a criam. E a criação da história não se destina a qualquer melhora ou a qualquer piora: ela só é o resultado da sempre repetida busca humana de viver e fazer a si mesma. E assim, da mesma maneira que cada ente humano, a história é indeterminada e gratuita.

E ainda mais àquele que não pode se inserir efetivamente nela como se ela realmente lhe "tocasse" ao mesmo tempo que não pode abandoná-la inteiramente, ao menos enquanto houver história. Se se admite que a humanidade não é uma espécie eterna, Fosca supera a própria história. É um estrangeiro incapaz de habitar não somente o mundo humano, mas também o universo. E não pode nunca abandonar essa condição de absoluto deslocamento em todo lugar e tempo, pois Fosca não pode renunciar a ser uma consciência e, consequentemente, não pode submergir insensível em um mundo que é totalmente sem sentido, como coisa entre as coisas. Aqui cabe o que diz Camus:

Se eu fosse uma árvore entre as árvores, gato entre os animais, a vida teria um sentido, ou antes, o problema não teria sentido porque eu faria parte desse mundo. Eu seria esse mundo ao qual me oponho com toda a minha consciência e exigência de familiaridade. Esta razão, tão irrisória, é a que me opõe a toda criação. (CAMUS, 2014, p.64).

Lembremos que Fosca não é o único ente imortal do universo. Há também aquele camundongo que primeiro experimentou o elixir da imortalidade. Ele também viverá para sempre. Mas não compartilha da mesma situação do conde, pois desconhece sua imortalidade e "gira sem cessar". Ele não é uma consciência do mundo e diante do mundo como no caso de 
Fosca. A imortalidade deste não lhe nega a humanidade, e propriamente enquanto humano, não poderá nunca deixar de ser uma oposição ao mundo, pois é justamente uma consciência que não deixa de ser. Se entendermos junto de Camus que a condição de humanidade é análoga à do personagem mitológico Sísifo, podemos, talvez, concluir que ninguém se aproxime tanto de Sísifo quanto Fosca.

Segundo Camus, o absurdo não é uma conclusão, mas um ponto de partida. Trata-se de uma primeira verdade a partir da qual todas as outras serão buscadas. Mas o absurdo aqui também nasce de um esforço inútil: a consciência humana busca compreender e dar sentido a um mundo que se mostra impenetrável. A impossibilidade de dar ao mundo e a si mesmo um fundamento e buscar compreender a esse mundo são atitudes iguais: deseja-se sempre superar essa estranheza contingente e instável que é ser, sem prerrogativas e justificações. Como diz Camus:

Um mundo que se pode explicar, mesmo com raciocínios errôneos, é um mundo familiar. Mas num universo repentinamente privado de ilusões e de luzes, pelo contrário, o homem se sente um estrangeiro. É um exílio sem solução, porque está privado das lembranças de uma pátria perdida. ou da esperança da terra prometida. Esse divórcio entre o homem e sua vida, o ator e seu cenário, é o sentimento do absurdo. (CAMUS, 2014, p.20).

Dado o absurdo, a questão que Camus levanta é a de se é possível ou coerente continuar a viver em um mundo injustificado e sem sentido aparente, permeado pelo sentimento e noção do absurdo, sem que se busque suprimir o problema através do suicídio ou por meio da esperança, seja de um além-túmulo, seja através de um grande ideal? A resposta é negativa. Acabar com a vida ou abraçar-se com fervor a uma crença qualquer não resolve o problema, pois o absurdo em si é contradição, resultado da incompatibilidade entre uma consciência que busca explicações e um mundo que não as fornece. As alternativas - o suicídio ou a esperança - não dão solução a essa contradição, apenas suprimem-na sem resposta. O mundo permanece carente de explicação, o que não significa que é necessário por isso abandonar a vida. Pelo contrário, pois a vida “(...) será tanto melhor vivida quanto menos sentido tiver" (CAMUS, 2014, p.66). Porque, apesar do absurdo, resta-nos ainda uma postura de revolta contra ele, contra esse silêncio do mundo em que estão guardados a miséria, o sofrimento e a morte. Viver é um esforço que, no fundo, é vão. E nisso nos assemelhamos a Sísifo. Esse herói mitológico fora condenado pelos deuses a rolar perpetuamente uma rocha ao cimo de uma montanha. A cada conclusão dessa tarefa, a rocha despenca novamente ao sopé, de onde Sísifo deve recomeçar seu trabalho sem propósito e 
esperança. É algo totalmente inútil e destituído de sentido, mas inescapável. Por isso, "Sísifo é o herói do absurdo. Tanto por causa de suas paixões como por seu tormento. Seu desprezo pelos deuses, seu ódio à morte e sua paixão pela vida lhe valeram esse suplício indizível no qual todo o ser se empenha em não terminar coisa alguma" (CAMUS, 2014, p.138). E uma vida humana é semelhante à pena de Sísifo: um esforço constante que nunca conclui nada e acaba sempre em nada. O que não implica, não obstante, uma conclusão pessimista: a tragédia de viver não basta para mergulhar a vida na pura negação. Ela simplesmente é assim, mas é de tal forma que é o objeto de um desejo insaciável. Pretende-se a vida apesar de tudo.

Fosca e Sísifo se assemelham pelo peso de suas penas: nunca hão de deixar de pagá-las. Diferente do comum da humanidade, da massa incontável dos mortais, para Fosca e Sísifo o absurdo é eterno. Cada indivíduo mortal pode erguer contra a morte a mais altiva revolta, pode desejar avidamente manter a tensão absurda que é seu próprio ser, mas, no fim, toda atitude sua é inofensiva ao destino: o absurdo individual tem de ser suprimido pela morte. Para Fosca, todavia, o absurdo nunca se encerrará. Errando pelo universo, é o companheiro desconhecido de Sísifo, que rola sua rocha no inferno: ambos estão aí, calcados no absurdo por toda a eternidade. Nada resta a esses dois além do enfrentamento da própria situação, de investir contra ela sua paixão infrutífera: Sísifo contra o veredito dos deuses, Fosca contra sua própria mortalidade. A este, em particular, nada há além da revolta de tentar romper seu estranhamento em relação a toda a humanidade e buscar o retorno ao convívio humano, ser homem entre os homens, mesmo que no fim sempre malogre. Do mesmo modo a Régine,, se voltarmos a pensar nela, o que resta é também a revolta, uma revolta contra a morte. Para ambos, portanto, resiste ainda uma insatisfação que não pode deixar de ser irresoluta. A eles só resta, por fim, essa paixão inquieta e inesgotável na busca de algo que nunca será. 


\section{Referências Bibliográficas}

CAMUS, A. O Mito de Sísifo. Rio de Janeiro: Record, 2014.

BEAUVOIR, S. O segundo sexo. Vol 1, Fatos e Mitos. São Paulo: Difusão Europeia do Livro, 1970.

. Por uma moral da ambiguidade. Rio de Janeiro: Nova Fronteira, 2005.

. Todos os homens são mortais. Rio de Janeiro: Nova Fronteira, 1983.

EMBAIXADA DA FRANÇA NO BRASIL. Marianne. Disponível em: https://br.ambafrance.org/Marianne . Acesso em: 01 de Fevereiro de 2018.

HEIDEGGER, Martin. Ser e Tempo. Petrópolis: Vozes, 2015.

ENCYCLOPEDIA BRITANNICA. Charles V. Disponível em: $<$ https://www.britannica.com/biography/Charles-V-Holy-Roman-emperor $>$. Acesso em: $01 \mathrm{de}$ Fevereiro de 2018.

SARTRE, Jean-Paul. O Ser e o Nada. Petrópolis: Vozes, 1997. 